\title{
Serum globulins and infection in mongolism
}

\author{
A. W. GRIFFITHS, P. E. SYLVESTER, AND E. MARY BAYLIS \\ From St Lawrence's Hospital, Caterham, Surrey, and the Area Laboratory, West Park Hospital, \\ Epsom, Surrey
}

SYNOPSIS Comparisons are made between a large group of mongols cared for in institutions ancw their carefully matched controls in respect of $(a)$ serum levels of immuno- $\gamma$-globulin $(\gamma \mathrm{A}, \gamma \mathrm{G}$, an $\overline{5}$ $\gamma \mathrm{M})$ and $(b)$ the incidence of pyrexial illnesses over a retrospective five-year period. Male mongols are found to have higher levels of $\gamma \mathrm{A}$-globulin than their male controls and a higher incidence of pyrexial illnesses. Otherwise no significant differences were found. The findings are discussed inj the light of previous studies.

Mongols are generally regarded as being unduly susceptible to infections, an explanation having been sought in abnormal levels of serum proteins reported by many workers and summarized in Table I.

TABLE I

SERUM PROTEIN LEVELS IN MONGOLS

\begin{tabular}{|c|c|}
\hline Series & Serum \\
\hline Donner (1954) & $\begin{array}{l}\text { Albumin decreased and } \gamma \text {-globulin increased } \\
\text { except in mongols recently admitted to } \\
\text { institutions. } \\
\text { Mean albumin decreased in comparison } \\
\text { with mentally defective controls also in } \\
\text { institutions. } \\
\text { Mean } \gamma \text {-globulin increased in comparison } \\
\text { with normals but not significantly in } \\
\text { comparison with mentally defective controls } \\
\text { in institutions. }\end{array}$ \\
\hline Stern and Lewis (1957) & $\begin{array}{l}\text { Albumin decreased, especially in the age } \\
\text { group } 6-10, \gamma \text {-globulin increased }\end{array}$ \\
\hline $\begin{array}{l}\text { Sobel, Strazzulla, } \\
\text { Sherman, Elkan, } \\
\text { Morgenstern, Marius, } \\
\text { and Meisel (1958) }\end{array}$ & Albumin decreased, $\gamma$-globulin increased \\
\hline $\begin{array}{l}\text { Torre (1958) } \\
\text { Skanse and Laurell } \\
\text { (1962) }\end{array}$ & $\begin{array}{l}\text { Albumin decreased, } \gamma \text {-globulin increased } \\
\gamma \text {-Globulin increased }\end{array}$ \\
\hline $\begin{array}{l}\text { Borselli (1962) } \\
\text { Pritham, Appleton, } \\
\text { and Fluck (1963) }\end{array}$ & $\begin{array}{l}a-, \beta-, \text { and } \gamma \text {-Globulins increased } \\
\text { Albumin decreased, } \gamma \text {-globulin increased, } \\
\gamma \text {-globulin mobility decreased, but no } \\
\text { significant differences found between } \\
\text { mongols not in institutions and normal } \\
\text { controls }\end{array}$ \\
\hline $\begin{array}{l}\text { Stiehm and Fude } \\
\text { (1966) }\end{array}$ & $\begin{array}{l}\gamma \mathbf{G} \text { Globulin increased, } \gamma \mathrm{A} \text { globulin in- } \\
\text { creased, } \gamma \mathbf{M} \text { globulin decreased, in compar- } \\
\text { ison with normals, the differences being } \\
\text { confined to adults }\end{array}$ \\
\hline Adi & $\begin{array}{l}\gamma \mathbf{G} \text { Globulin increased in comparison with } \\
\text { normal controls. }\end{array}$ \\
\hline
\end{tabular}

It has been suggested that in mongolism, the increased level of $\gamma$-globulin represents an attempt to compensate for some deficiency in its effectiveness.

Received for publication 17 May 1968
In this context it must be remarked that Siege (1948) and Mande, Desclaux, Soulairac, anc․ Beucher (1952) demonstrated decreased antibody levels in mongols after immunization. It was there $\vec{\imath}$ upon decided to investigate the matter further bye estimating serum globulin fractions in a large group of mongols and carefully matched controls as paro of a concomitant investigation proceeding into their relative capacity to produce antibodies afte tetanus vaccination. The latter study has been completed (Griffiths and Sylvester, 1967), no significant differences having been found betweer mongol and control groups. The following report is concerned with their $\gamma$-globulin fractions.

\section{POPULATION}

Subjects and controls were inpatients of St Lawrence' Hospital, Caterham, a large institution for the treatmen of the mentally subnormal admitted largely from the London area.

\section{SAMPLE}

Only those mongols in whom chromosome studies hat demonstrated absence of mosaicism and translocation were considered. From these, 48 were randomly selected and matched with the same number of controls of similat age and sex and resident for a similar period. Aln patients were free from active physical disease. Procedures were explained to the next of kin and their consent was obtained. Blood specimens were withdrawn at approxie mately the same time of day.

\section{METHOD}

Immunoglobulins were measured on immunodiffusiond plates $^{1}$ obtainable commercially (Darcy, 1960; Crowle 1961; Grabar, 1963).

${ }^{1}$ Hyland Laboratories, Los Angeles, California. 
The sera were estimated in random batches of 50 to 60 samples. Initially duplicate determinations were performed and were found to give results in close agreement. A series of reference standards ${ }^{1}$ was estimated with each batch. The results were expressed as $\mathrm{mg}$ per $100 \mathrm{ml}$ immunoglobulin.

\section{DATA}

These are set out in Tables II and III, figures for controls being bracketed.

\section{TABLE II}

\begin{tabular}{|c|c|c|c|c|c|c|c|c|}
\hline \multirow{2}{*}{$\begin{array}{l}\text { Pair } \\
\text { No. }\end{array}$} & \multirow{2}{*}{$\begin{array}{l}\text { Age } \\
\text { in } \\
\text { Years }\end{array}$} & \multirow{2}{*}{$\begin{array}{l}\text { Duration of } \\
\text { Hospital } \\
\text { Stay }(y r)\end{array}$} & \multicolumn{5}{|c|}{ MALES } & \\
\hline & & & $\gamma, A$ & & $\gamma G$ & & $\gamma M$ & \\
\hline 1 & 62 & 43 & 330 & (178) & 1,210 & $(1,830)$ & 98 & (180) \\
\hline 2 & 58 & 41 & 295 & (240) & 1,290 & $(1,350)$ & 81 & (218) \\
\hline 3 & 16 & 8 & 280 & (160) & 1,470 & $(1,150)$ & 119 & (254) \\
\hline 4 & 23 & 17 & 420 & (264) & 2,050 & (684) & 133 & (174) \\
\hline 5 & 19 & 13 & 215 & (275) & 1,200 & $(1,100)$ & 76 & (187) \\
\hline 6 & 53 & 43 & 267 & (265) & 890 & $(1,100)$ & 200 & (90) \\
\hline 7 & 38 & 21 & 595 & (570) & 1,430 & $(2,140)$ & 196 & (198) \\
\hline 8 & 29 & 20 & 255 & (185) & 1,510 & $(1,940)$ & 138 & (230) \\
\hline 9 & 27 & 7 & 560 & (187) & 1,380 & (760) & 148 & (304) \\
\hline 10 & 26 & 9 & 250 & (520) & 1,850 & $(850)$ & 167 & (353) \\
\hline 11 & 33 & 22 & 345 & (330) & 1,220 & (905) & 135 & $(420)$ \\
\hline 12 & 13 & 7 & 234 & (280) & 460 & $(1,050)$ & 86 & (95) \\
\hline 13 & 27 & 14 & 475 & (303) & 1,550 & $(1,460)$ & 125 & (116) \\
\hline 14 & 30 & 14 & 810 & (204) & 1,850 & $(1,200)$ & 105 & (63) \\
\hline 15 & 31 & 26 & 940 & (298) & 890 & (760) & 354 & (84) \\
\hline 16 & 29 & 14 & 445 & (135) & 1,260 & $(1,430)$ & 300 & (132) \\
\hline 17 & 28 & 14 & 330 & (173) & 1,130 & (870) & 231 & (49) \\
\hline 18 & 46 & 32 & 520 & $(500)$ & 280 & $(1,040)$ & 54 & (610) \\
\hline 19 & 40 & 21 & 520 & (415) & 352 & $(1,130)$ & 156 & (230) \\
\hline 20 & 29 & 21 & 31 & (242) & 1,750 & $(1,550)$ & 104 & (140) \\
\hline 21 & 28 & 14 & 288 & (520) & 1,240 & $(1,050)$ & 103 & (155) \\
\hline 22 & 34 & 19 & 610 & (245) & 1,560 & $(1,050)$ & 184 & (57) \\
\hline 23 & 29 & 20 & 400 & (251) & 1,250 & $(1,120)$ & 285 & (260) \\
\hline 24 & 37 & 10 & 385 & (330) & 880 & $(1,210)$ & 160 & (98) \\
\hline
\end{tabular}

The Wilcoxon two-tailed signed ranks test was applied to the data, the following results being obtained: (1) no significant differences between mongol and control groups of each sex were found in respect of the $\gamma \mathrm{G}$ and $\gamma \mathrm{M}$ fractions. (2) In the males (but not the females) the $\gamma \mathrm{A}$ fraction was found to be significantly higher $(\mathrm{P}<0.02>0.01)$ in the mongols than in the controls.

In view of these interesting findings it was decided to ascertain whether there had been in actual fact any difference between the number of infections incurred in these two groups. The relevant records were accordingly searched and all pyrexial illnesses occurring during the preceding five years were enumerated. The totals are given below.

\begin{tabular}{lcccc} 
Mongols & & & Controls & \\
\cline { 5 - 5 } & Female & & Male & Female \\
\hline 50 & 43 & 30 & 33
\end{tabular}

The data were investigated by the Wilcoxon two-tailed signed ranks test and there were found to be a significantly higher number of infections in the male group only.

${ }^{1}$ Hyland Laboratories: Hoechst Behringwerke, A.G.
TABLE III

FEMALES

\begin{tabular}{|c|c|c|c|c|c|c|c|c|}
\hline \multirow{2}{*}{$\begin{array}{l}\text { Pair } \\
\text { No. }\end{array}$} & \multirow{2}{*}{$\begin{array}{l}\text { Age } \\
\text { in } \\
\text { Years }\end{array}$} & \multirow{2}{*}{$\begin{array}{l}\text { Duration of } \\
\text { Hospital } \\
\text { Stay }(y r)\end{array}$} & \multicolumn{6}{|c|}{ Immunoglobulins (mg/100 ml) } \\
\hline & & & $\gamma A$ & & $\gamma G$ & & $\gamma M$ & \\
\hline 1 & 27 & 11 & 355 & (157) & 1,200 & $(1,250)$ & 163 & (194) \\
\hline 2 & 20 & 8 & 177 & (253) & 1,250 & $(1,150)$ & 148 & (203) \\
\hline 3 & 22 & 15 & 200 & (450) & 1,350 & $(1,050)$ & 171 & (150) \\
\hline 4 & 20 & 10 & 460 & $(610)$ & 1,050 & (850) & 187 & (440) \\
\hline 5 & 25 & 11 & 590 & (283) & 1,530 & $(1,120)$ & 250 & (240) \\
\hline 6 & 20 & 14 & 200 & $(760)$ & 1,240 & $(1,300)$ & 99 & (620) \\
\hline 7 & 18 & 8 & 137 & (380) & 905 & $(1,250)$ & 58 & (550) \\
\hline 8 & 36 & 9 & 445 & (197) & 1,200 & $(1,050)$ & 266 & (192) \\
\hline 9 & 26 & 21 & 177 & (570) & 1,450 & $(1,170)$ & 156 & (123) \\
\hline 10 & 33 & 17 & 285 & (148) & 1,700 & (980) & 199 & (191) \\
\hline 11 & 22 & 14 & 312 & (460) & 1,450 & $(1,150)$ & 199 & (475) \\
\hline 12 & 50 & 33 & 212 & (178) & 1,800 & $(1,150)$ & 75 & (192) \\
\hline 13 & 25 & 15 & 184 & (340) & 1,200 & $(1,300)$ & 190 & (194) \\
\hline 14 & 41 & 21 & 605 & (490) & 703 & (860) & 85 & (274) \\
\hline 15 & 41 & 28 & 340 & (235) & 1,200 & (950) & 314 & (97) \\
\hline 16 & 17 & 10 & 285 & (630) & 1,030 & $(850)$ & 178 & (325) \\
\hline 17 & 31 & 14 & 560 & (420) & 1,250 & $(1,120)$ & 255 & (236) \\
\hline 18 & 22 & 7 & 330 & (321) & 3,740 & $(1,550)$ & 163 & (148) \\
\hline 19 & 42 & 22 & 270 & (460) & 1,750 & $(1,300)$ & 90 & (465) \\
\hline 20 & 19 & 8 & 240 & (79) & 1,350 & $(1,500)$ & 158 & (238) \\
\hline 21 & 26 & 9 & 401 & (360) & 1,100 & $(1,470)$ & 129 & (101) \\
\hline 22 & 44 & 34 & 850 & (173) & 1,200 & $(1,350)$ & 287 & (194) \\
\hline 23 & 24 & 12 & 420 & (188) & 910 & (980) & 304 & (190) \\
\hline 24 & 50 & 34 & 660 & (285) & 1,250 & $(1,500)$ & 213 & (192) \\
\hline
\end{tabular}

\section{DISCUSSION}

The previous work reviewed indicates that mongolism is associated with serum $\gamma$-globulin concentrations which are increased in comparison with normal controls; it is less clear, however, whether differences exist between mongols in institutions and mental defectives also in institutions as a whole. Griffiths (1965) has suggested that hyperglobulinaemia may be a function of mental defectives confined to institutions in general, and accounted for by their lower standards of personal hygiene, the spread of common infections, and the extensive immunization programmes to which they are often subjected. The present study has sought to clarify the problems by the employment of large groups of mongols and carefully matched controls, this latter requirement having been emphasized but not always observed by previous workers in this field.

Two interesting findings have emerged, both concerning only the male patients.

1 The mongol group was shown to have very significantly higher levels of $\gamma \mathrm{A}$ globulin. Although the other globulin fractions were similar, it is not unlikely that increased levels of $\gamma \mathrm{A}$ globulin have accounted for the findings of increased total $\gamma$-globulin in some of the mongol groups previously studied. It is of interest that this particular immunoglobulin is predominant in certain secretions, including those of nose and bronchi, and is believed to participate in a local antibody system protecting the mucous surfaces, the evidence being admirably 
summarized by South, Warwick, Wollheim, and Good (1967). The association with infections common in mongolism need hardly be mentioned.

2. Male mongols were shown to have an increased frequency of infections. There is, of course, good evidence (Penrose and Smith, 1966) that the mortality of mongols is higher than that of the general population and that infections account for a large proportion of their deaths. It might seem from the present study that as far as defectives in institutions are concerned, increased mongol morbidity affects chiefly the males.

The question must arise as to whether the abnormal level of $\gamma \mathrm{A}$ globulin is a cause or an effect of the increased infectivity. A causal relationship is suggested by evidence quoted by Stiehm and Fudenberg that chronic infection usually leads to elevation of all three immune globulins. On the other hand, high serum levels of $\gamma \mathrm{A}$ globulin have been found in patients with cystic fibrosis and chronic respiratory infection (South et al., 1967) and it is suggested that such levels may be secondary to the involvement of the $\gamma \mathrm{A}$ system. Vitamin A dyș metabolism is, perhaps, the underlying factor.

\section{REFERENCES}

Adinolfi, M., Gardner, B., and Martin, W. (1967). J. clin. Path $20,860$.

Borselli, L. (1962). Ann. Isnardi Auxl., 9, 105.

Crowle, A. J. (1961). Immunodiffusion. Academic Press, New York.

Darcy, D. A. (1960). Immunology, 3, 325.

Donner, M. (1954). Ann. Med. exp. Fenn., 32, suppl. 9.

Grabar, P. (1963). Nature (Lond.), 197, 692.

Griffiths, A. W. (1965). J. ment. Defic. Res., 9, 164.

- , and Sylvester, P. E. (1967). Ibid., 11, 263.

Mande, R., Desclaux, P., Soulairac, A., and Beucher (1952). Anfiv med. Psychol., 110, 304. menrose, L. S., and Smith, G. F. (1966). Down's Anomaly. Churchigg
London.

Pritham, G. H., Appleton, M. D., and Fluck, E. R. (1963). Amer. స̂ ment. Defic., 67, 517.

Siegel, M. (1948). Amer. J. Hyg., 48, 63.

Skanse, B., and Laurell, C. B. (1962). Acta med. scand., 172, 63.

Sobel, A. E., Strazzulla, M., Sherman, B. S., Elkan, B., Morgensterm S. W., Marius, N., and Meisel, A. (1958). Amer. J. ment Defic., 62, 642.

South, M. A., Warwick, W. J., Wollheim, F. A., and Good, R. A (1967). J. Pediat., 71, 645,

Stern, J., and Lewis, W. H. P. (1957). J. ment. Sci., 103, 222.

Stiehm, E. R., and Fudenberg, H. H. (1966). Pediatrics, 37, 715.

Torre, M. (1958). G. Psichiat. Neuropat., 86, 17. 